\title{
PENGARUH LAYANAN KONSELING INDIVIDUAL TERHADAP PERKEMBANGAN KONSEP DIRI SISWA KELAS X SMA MELATI BINJAI TAHUN PELAJARAN 2018/2019
}

\author{
Hadi Widodo \\ Dosen STKIP Budidaya Binjai
}

\begin{abstract}
ABSTRAK
Permasalahan yang dibahas dalam penelitian ini adalah layanan Konseling Individual dan Perkembangan Konsep Diri siswa di kelas X SMA Melati Binjai Tahun Pelajaran 2018/2019.

Populasi berjumlah dua ratus Sembilan puluh dua orang siswa, terdiri 42 orang siswa. Sampel sejumlah dengan jumlah populasi. Jenis penelitian yang digunakan pada penelitian ini adalah penelitian eksperimen.

Hasil perhitungan rasio $t$ selanjutnya dikonfirmasi dengan nilai $t_{\text {kritis }}$ pada taraf signifikan 5\% kebebasan $(\mathrm{dk})\left(\mathrm{n}_{\mathrm{e}+} \mathrm{n}_{\mathrm{k}}-2\right.$ maka $\mathrm{t}_{\text {tabel }}=\mathrm{t}\left((1-1 / 2 \alpha)(\mathrm{dk}),\left(\mathrm{t}_{\text {tabel }}\right.\right.$ lihat lampiran) Kriteria pengujian terima $\mathrm{H}$ ajika $\mathrm{t}$ hitung $>\mathrm{t}_{\text {tabel. }}$. Nilai $\mathrm{t}$ dengan taraf signifikan $5 \%$ atau 0,05 . Berdasarkan pada tabel $t$, nilai $t_{\text {tabel }}=1,312$. Jika $t_{\text {hitung }}$ telah diketahui sebesar 5,022, maka pengujian kriteria hipotesis diterima. Maka dapat disimpulkan bahwa "Konseling individu Sangat Berpengaruh Dalam Perkembangan Konsep diri Siswa Kelas X SMA Melati Binjai 2018/2019.”
\end{abstract}

Kata kunci :pengaruh layanan konseling individual perkembangan konsep diri

\section{A. PENDAHULUAN}

Konsep diri adalah suatu kemampuan mental untuk mampu mengurangi pengaruh yang ada, yaitu pengaruh negatif dari keraguan yang ada pada diri manusia, dengan demikian biarkan rasa percaya diri setiap orang digunakan pada kemampuan dan pengetahuan personal untuk memaksimalkan efek. Percaya diri mempunyai arti yang berbeda antara mengetahui bagaimana melakukakna sesuatu dan bagaimana sebenarnya melakukannya, jika hal itu diperhatikan. Gaya hidup kesibukan yang dialami pada saat ini sangat mempengaruhi akan kulitas diri seseorang, dengan adanya konsep kepercayaan diri manusia akan lebih mampu untuk menuju kearah yang lebih baik.

Konsep diri merupakan faktor penting di dalam berinteraksi dan beradaptasi dengan lingkungan. Setiap individu dapat saja menyadari keadaannya atau identitas yang dimilikinya akan tetapi yang lebih penting adalah menyadari seberapa baik atau buruk keadaan yang dimiliki serta bagaimana harus bersikap terhadap keadaan tersebut. Tingkah laku individu sangat bergantung pada kualitas konsep dirinya. 


\section{Jurnal Serunai Ilmu Pendidikan \\ Vol.3, No.2, Juni 2018 \\ e-ISSN 2621-2676}

Menurut Hariyanto, konsep diri adalah: "kondisi mental atau psikologis diri seseorang yang memberi keyakinan kuat pada dirinya untuk berbuat atau melakukan sesuatu tindakan. Orang yang tidak percaya diri memiliki konsep diri negatif, kurang percaya pada kemampuannya, karena itu sering menutup diri"1.

Konseling merupakan pelayanan terpenting dalam program bimbingan. Layanan ini memfasilitasi siswa untuk memperoleh bantuan pribadi secara langsung, baik secara face to face maupun melalui media (telepon atau internet)

dalam memperoleh kemampuan untuk mengembangkan konsep diri. Menurut Tohirin," konseling individu merupakan salah satu jenis

layanan yang dapat dilaksanakan konselor untuk membantu siswa dalam memecahkan masalah yang dihadapinya". ${ }^{2}$

Banyak siswa yang enggan membicarakan masalah pribadi atau urusan pribadi mereka dalam diskusi kelas dengan guru. Beberapa dari mereka ragu untuk berbicara di depan kelompok-kelompok kecil. Oleh karena itu, konseling individual dalam sekolahsekolah, tidak terlepas dari psikoterapi, didasarkan pada asumsi bahwa konseli itu akan lebih suka berbicara sendirian dengan seorang konselor.

Selain itu, kerahasiaan, selalu dianggap sebagai dasar konseling. Akibatnya, muncul asumsi bahwa siswa membutuhkan pertemuan pribadi dengan seorang konselor untuk mengungkapkan pikiran mereka dan untuk meyakinkan bahwa pengungkapan mereka akan dilindungi. Tidak ada yang lebih aman daripada konseling individual.

Harapan besar ditumpukan pada para penyelenggara layanan bimbingan dan konseling di sekolah (konselor). Beragam gangguan dan hambatan yang dialami seorang konselor, mulai dari jumlah tenaga yang masih terbatas sehingga semua orang "merasa" diperbolehkan melaksanakan tugas tersebut sampai dengan pelaksanaan layanan bimbingan dan konseling yang belum optimal. Layanan konseling individu yang dimungkinkan dapat membantu siswa dalam mengenal dan memahami diri baik dari segi kelebihan dan kekurangan sehingga dapat menyelesaikan permasalahan yang ada pada dirinya maupun masalah yang dihadapinya.

${ }^{1}$ Hariyanto,http://www. Ilmupsikologi.wordpress.com/2009/12/25/pengertian kepercaya an-diril. Di akses tanggal 04 September 2015.

2 Tohirin, Bimbingan dan Konseling di Sekolah dan Madrasah, ( Jakarta: Raja Grafindo Persada, 2007), hlm 164 


\section{B. METODOLOGI PENELITIAN}

\section{Populasi dan Sampel Penelitian}

\section{a. Populasi penelitian}

Menurut Sugiyono," Populasi adalah wilayah generalisasi yang terdiri atas: obyek/subyek yang mempunyai kualitas dan karakteristik tertentu yang ditetapkan oleh peneliti untuk dipelajari dan kemudian ditarik kesimpulannya."3 Populasi dalam penelitian ini adalah siswa kelas X SMA Melati Binjai kelas X yang berjumlah 42 orang.

\section{a. Sampel penelitian}

Menurut Sudjana Sampel adalah bagian dari populasi yang diambil untuk dijadikan penelitian. ${ }^{4}$ Kemudian Arikunto mengemukakan: "apabila jumlah subjeknya kurang dari 100 maka lebih baik diambil semua sehingga penelitiannya merupakan penelitian populasi. Populasi siswa 42 siswa.

\section{Instrumen Penelitian}

\section{a. Pengertian Instrument penelitian}

Menurut Arikunto, "Instrumen penelitian adalah alat atau fasilitas yang digunakan oleh peneliti dalam mengumpulkan data agar pekerjaannya lebih mudah dan hasilnya lebih baik, dalam arti lebih cermat, lengkap, dan sistematis

sehingga lebih mudah diolah".

Dalam penelitian ini penulis akan menggunakan angket. "Angket adalah sejumlah pertanyaan yang digunakan untuk memperoleh Konseling Individual dari responden dalam arti laporan tentang pribadinya, atau hal-hal yang ia ketahui". ${ }^{6}$

Alat pengumpulan data ini digunakan karena dapat menghemat waktu dan dan dapat menghimpun data atau Konseling Individual yang dibutuhkan dengan waktu relatif singkat. Setiap responden akan menerima pertanyaan dan kemungkinan jawaban yang sama, hal ini akan memudahkan penulis untuk mengelola dan menganalisis data yang diperoleh.

\section{Jenis Penelitian}

Jenis penelitian yang digunakan pada penelitian ini adalah penelitianeksperimen. Menurut Arikunto, eksperimen adalah suatu cara untukmencari hubungan sebab akibat 117

${ }^{3}$ Sugiyono,Metode Penelitian Pendidikan, Cet Ke 11( Bandung: Alfabeta, 2010), hlm

${ }^{4}$ Sudjana. Metoda Statistika.( Bandung: Tarsito, 2005), hlm 6

5 Suharsimi Arikunto, Prosedur Penelitian Suatu Pendekatan Praktik,(Jakarta: Rineka Cipta, Edisi Revisi, 2010), hlm. 203

${ }^{6}$ Ibid, hlm. 124. 


\section{Jurnal Serunai Ilmu Pendidikan \\ Vol.3, No.2, Juni 2018 \\ e-ISSN 2621-2676}

(hubungan kausal) antara dua faktor yang sengajaditimbulkan oleh peneliti dengan mengeliminasi atau mengurangi ataumenyisihkan faktor-faktor lain yang mengganggu. ${ }^{7}$

Jadi dapat dipahami bahwa eksperimen adalah suatu penelitian yangberusaha mencari pengaruh variabel tertentu terhadap variabel yang lain dalamkondisi yang terkontrol secara ketat. Alasan peneliti menggunakan eksperimendalam penelitian ini adalah untuk melihat akibat dari suatu perlakuan (layananklasikal menggunakan teknik sosiodrama) terhadap variabel yang lain (perilakuagresif).

\section{Desain Penelitian}

Desain penelitian adalah semua proses yang diperlukan dalam perencanaandan pelaksanaan penelitian. Desain penelitian yang digunakan adalah the onegroup pretestposttest design. The one group pretest-posttest design adalahpenelitian eksperimen dimana sebelum diberi perlakuan dilakukan pretest terlebihdahulu, hasil perlakuan dapat diketahui dengan lebih akurat, karena dapatmembandingkan dengan keadaan sebelum diberi perlakuan. ${ }^{8}$

\section{Rancangan Penelitan}

Sebelum melaksanakan penelitian, yang harus dilakukan terlebih dahuluadalah membuat rancangan penelitian, agar pelaksanaan penelitian lebih terarahdan sistematis. Rancangan penelitian untuk penelitian ini adalah sebagai berikut.

\section{a. Pre - Test}

Pre test dilakukan pada siswa yang memiliki konsep diri denganmelakukan pengamatan dan wawancara mendalam dengan guru kelas. Tujuanpelaksanaan pre test dalam penelitian ini adalah untuk mengetahui tingkatkonsep diri siswa sebelum diberi tretment.

\section{b. Treatment}

Perlakuan diberikan melalui layanan konseling menggunakan teknik konseling individu .

\section{c. Post - Test}

Pada tahapan ini, post-test merupakanpengukuran kepada responden setelah diberikan treatmentatau perlakuan yaitu layanan konseling individu . Post-test dilakukan pada siswa yang memiliki konsep diri denganmelakukan pengamatan dan wawancara mendalam dengan guru kelas. Tujuanpelaksanaan post-test dalam

\footnotetext{
${ }^{7}$ Suharsimi Arikunto. Prosedur Penelitian (Jakarta : Rineka Cipta, 2006). hlm. 3.

${ }^{8}$ Ibid. hlm. 6.
} 
penelitian ini adalah untuk mengetahui keberhasilan dalam pelaksanaan tratment, dan untuk mengetahui apakah konsep diri sudah mengalami penurunan atau teratasi.

\section{Subjek Penelitian}

Subyek Penelitian merupakan pihak-pihak yang dijadikansebagai sampel dalam sebuah penelitian. Subjek penelitian juga membahaskaraketeristik subjek yang digunakan dalam penelitian, termasuk penjelasanmengenai populasi, sampel dan teknik sampling (acak / non-acak) yang digunakan. ${ }^{9}$

Pengambilan subyek penelitian dalam penelitian ini dilakukan dengan caramelihat dan mengklasifikasikan dengan kriteria berdasarkan pada hasil observasi awal yang telah dilakukan peneliti sebagai berikut : (1) Siswa kelas X SMA Melati Binjai yang berjumlah 42 .

\section{Variabel Penelitian}

Pada umumnya orang melakukan penelitian dengan menggunakan lebih dari satu variabel, yaitu variabel bebas dan variabel terikat ${ }^{10}$.Hal ini sejalan dengan yang diungkapkan dengan Arikunto "Variabel adalah suatu atribut sifat atau nilai dari orang, objek atau kegiatan yang mempunyai variasi tertentu yang ditetapkan oleh peneliti untuk dipelajari kesimpulannya. ${ }^{11}$

Variabel yang digunakan dalam penelitian ini yaitu variabel bebas dan variabel terkait $^{12}$.

\section{Teknik Analisis Data}

Data yang diperoleh dianalisis dengan teknik statistik asosiatif dilakukan dengan langkah - langkah sebagai berikut :

\section{1) Menentukan Mean}

Dengan menggunakan rumus:

$$
\begin{aligned}
& \bar{X}=\frac{\sum X_{i}}{n} \\
& \bar{Y}=\frac{\sum Y_{i}}{n}
\end{aligned}
$$

\section{2) Standard Deviasi}

\footnotetext{
${ }^{9}$ Ibid. hlm 55.

${ }^{10}$ Ibid. hlm.54.

${ }^{11}$ Ibid hlm 63

${ }^{12}$ Ibid. hlm 64
} 


$$
\begin{aligned}
& S_{x}=\sqrt{\frac{n \sum X^{2}-\left(\sum X\right)^{2}}{n(n-1)}} \\
& S_{y}=\sqrt{\frac{n \sum Y^{2}-\left(\sum Y\right)^{2}}{n(n-1)}}
\end{aligned}
$$

\section{3) Uji Normalitas}

Uji normalitas mengikuti prosedur yang dalam Sudjana adalah: ${ }^{13}$

a. Pengamatan $X_{1}, X_{2}, \ldots \ldots X_{n}$ dijadikan angka baku $Z_{1}, Z_{2}, \ldots \ldots Z_{n}$ dengan menggunakan rumus:

$Z_{1}=\frac{X_{i}-\bar{X}}{S}$

( $\bar{X}$ dan $\mathrm{S}$ masing-masing merupakan rata-rata dan simpangan baku dari sampel)

b. Untuk itu tiap angka baku ini dan menggunakan daftar distribusi moral baku, kemudian dihitung peluang $\mathrm{F}\left(\mathrm{Z}_{\mathrm{i}}\right)=\mathrm{P}\left(\mathrm{Z} \leq \mathrm{Z}_{\mathrm{i}}\right)$

c. Selanjutnya hitung proporsi $Z_{1}, Z_{2}, \ldots \ldots Z_{n}$ yang lebih kecil atau sama dengan $Z_{1}$ jika proporsi ini berdasarkan pada $S\left(Z_{i}\right)$ maka:

$\mathrm{SZ}_{\mathrm{i}}=$

d. Hitung selisih $\mathrm{F}\left(\mathrm{Z}_{\mathrm{i}}\right)-\mathrm{S}\left(\mathrm{Z}_{\mathrm{i}}\right)$ kemudian tentukan harga mutlaknya.

Ambil harga yang besar diantara harga mutlak tersebut. Sebut harga mutlak sebesar ini $\mathrm{L}_{\mathrm{o}}$ kemudian $\mathrm{L}_{\mathrm{o}}$ ini dibandingkan dengan harga $\mathrm{L}_{\text {label }}$ yang diambil dalam nilai kritik untuk uji Liliefors dengan taraf nyata $\alpha=0,05$. Kriteria pengujian adalah diterima data berdistribusi normal bila $\mathrm{L}_{\mathrm{o}}<\mathrm{L}_{\text {label }}$ dalam hal lainnya hipotesis ditolak.

\section{4) Uji Homogenitas Data.}

Pengujian homogenitass adalah mengenai sama tidaknya variansi-variansi dua buah distribusi atau lebih. Uji homogenitas yang akan di bahas dalam tulisan ini adalah uji homogenitas variansi dan uji burlett. Uji homogenitas di lakukan untuk mengetahui apakah data dalam variabel $\mathrm{X}$ dan $\mathrm{Y}$ bersifat homogen atau tidak.

Untuk menguji apakah kedua kelompok homogeny, akan diuji hipotesis sebagai berikut :

Ha $: \alpha 1^{2}=\alpha 2^{2}$

\footnotetext{
${ }^{13}$ Nana Sudjana.Metode Statistik. (Bandung :Tarsito,2007)hlm. 446-447.
} 
Ho $: \alpha 1^{2} \neq \alpha 2^{2}$

Rumus statistik yang digunakan adalah :

Fhitung $=\frac{S_{1}^{2}}{S_{2}^{2}} \ldots \ldots \ldots \ldots \ldots \ldots \ldots \ldots \ldots(\text { Sudjana })^{14}$

Kriteria Pengujian

Terima Ha Jika Fhitung $>$ Ftabel

\section{5) Pengujian Hipotesis}

Untuk mengetahui apakah ada pengaruh antar variabel bebas (X) dengan variabel terikat (Y) dalam mebuktikan benar atau tidaknya hipotesa yang di ajukan, maka uji perbedaan dua rata-rata yaitu uji t satu pihak, pihak kanan dengan rumus uji t. Menurut Arikunto, uji t yang digunakan untuk varians antara kedua kelompok jika dikatakan homogen yaitu sebagai berikut $:^{15}$

$t_{\text {hitung }}=\frac{X_{\mathrm{e}}-X_{K}}{\sqrt[s]{\frac{1}{n_{\mathrm{e}}}+\frac{1}{n_{k}}}}$

dengan $S_{\text {gab }}=\frac{\left(\mathrm{n}_{\mathrm{e}}-1\right) \mathrm{S}_{\mathrm{e}}^{2}+\left(\mathrm{n}_{\mathrm{k}}-1\right) \mathrm{S}_{\mathrm{k}}^{2}}{\mathrm{n}_{\mathrm{e}}+\mathrm{n}_{\mathrm{k}}-2}$

jika dikatakan heterogen maka rumus yang digunakan adalah sebagai berikut:

$\mathrm{t}_{\text {hitung }}=\frac{X_{1}-X_{2}}{\sqrt{\frac{s_{1}^{2}}{n_{1}}+\frac{s_{2}^{2}}{n_{2}}}}$

$\mathrm{t}_{\text {tabel }}=\frac{\left(\frac{s_{1}^{2}}{n_{1}}\right) t_{1}+\left(\frac{s_{2}^{2}}{n_{2}}\right)}{\left(\frac{s_{1}^{2}}{n_{1}}+\frac{s_{2}^{2}}{n_{2}}\right)}$

keterangan :

$\mathrm{X}_{1}=$ hasil skor rata - rata pretest

$\mathrm{X}_{2}=$ hasil rata - rata postest

$S_{1}^{2}=$ standard deviasi hasil rata - rata pretest

$S_{2}^{2}=$ standard deviasi hasil rata -rata posttest

$\mathrm{n}_{1}=$ jumlah anggota kelompok pretest

$\mathrm{n}_{2}=$ jumlah anggota kelompok postest

Jika hasil yang di peroleh nilai rata-rata pada kelas kontrol lebih kecil atau sama dengan nilai rata-rata pada kelas eksperimen, maka :

Ho : $\mu 1 \leq \mu 2$

${ }^{14}$ Nana Sudjana.Metode Statistik. (Bandung :Tarsito,2007)hlm.98

${ }^{15}$ Suharsimi Arikunto. Prosedur Penelitian (Jakarta: Rineka Cipta, 2006). hlm. 246-247 
dan jika hasil yang di peroleh nilai rata-rata kelas kontrol tidak sama dengan nilai rata-rata kelas eksperimen, maka :

Ha : $\mu 1 \neq \mu 2$

Keterangan :

$\mu 1:$ rata -rata Pretest

$\mu 2$ : rata -rata posttest

Arikunto menyatakan, hasil perhitungan rasio t selanjutnya dikonfirmasi dengan nilai $t_{\text {kritis }}$ pada taraf signifikan $5 \%$ kebebasan $(d k)\left(n_{e+} n_{k}-2\right.$ maka $t_{\text {tabel }}$

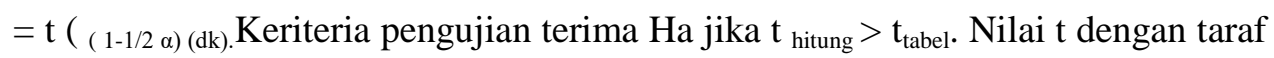
signifikan $5 \%$ atau $0,05 .^{16}$

\section{C.HASIL PENELITIAN}

\section{Deskripsi Data}

Penelitian yang dilakukan pada siswa kelas X SMA Melati Binjai Tahun Pelajaran 2018/2019 ini menggunakan metode penelitian kuantitatif eksperimen, dimana penelitian ini dilakukan untuk mengetahui Pengaruh pemberian konseling individu terhadap konsep diri siswa siswa yang dalam konteks ini, konsep diri siswa termasuk pada tindakan yang menimbulkan ketidak-nyamanan siswa dalam mengikuti pelajaran disekolah.

\section{Analisis Konsep diri Siswa}

Pada tahapan awal, peneliti ingin mengetahui sejauhmana tingkat agresifitas siswa dengan menggunakan angket konsep diri yang diberikan di awal bimbingan.

Setelah peneliti mendapatkan hasil jawaban angket konsep diri siswa sebagaimana tertera pada tabel di atas, maka peneliti dapat menyimpulkan bahwa masih terdapat konsep diri siswa yang berdampak negatif terhadap proses pembelajaran disekolahnya. Hal ini dapat di ketahui dari keseragaman pilihan jawaban yang siswa pilih.

Hal tersebut juga dapat dianalisis dengan mengetahui nilai rata-rata yang diperoleh siswa. Untuk mengetahui nilai rata-rata yang diperoleh siswa dalam menjawab pertanyaan angket konsep diri siswa, digunakan perhitungan sebagai berikut:

$$
\begin{aligned}
& \bar{X}=\frac{\sum X}{n} \\
& =\frac{1790}{30}
\end{aligned}
$$

\footnotetext{
${ }^{16}$ Ibid.
} 
$=59,667$

Berdasarkan pada perhitungan di atas, telah diketahui nilai rata-rata yang diperoleh siswa sebesar 59,667. Selanjutnya untuk mengetahui standar deviasi dari skor yang diperoleh siswa dapat menggunakan perhitungan sebagai berikut:

$$
\begin{aligned}
& S D_{x}=\sqrt{\frac{n \sum X^{2}-\left(\sum X\right)^{2}}{n(n-1)}} \\
& S D_{x}=\sqrt{\frac{30(107700)-1790^{2}}{30(30-1)}} \\
& S D_{x}=\sqrt{\frac{3231000-3204100}{870}} \\
& S D_{x}=\sqrt{\frac{26900}{870}} \\
& S D_{x}=\sqrt{30,9195} \\
& S D_{x}=5,56
\end{aligned}
$$

Dari perhitungan di atas, telah diketahui bahwa standar deviasi angket konsep diri siswa sebesar 5,56.

\section{Analisis Konseling individu}

Dalam tahapan ini, siswa diberikan bimbingan dengan menggunakan metode konseling individu, dimana siswa diberikan perlakuan dengan menghadapkan kondisi dan situasi yang sesuai dengan realita yang terjadi serta dampak dari setiap perilaku siswa. Selanjutnya siswa diberikan pertanyaan berupa angket konseling individu dengan hasil dapat dilihat pada tabel 4.2. Hasil Angket Konseling individu.

Setelah peneliti mendapatkan hasil jawaban angket konseling individu siswa sebagaimana tertera pada tabel di atas, maka peneliti dapat menyimpulkan bahwa konsep diri siswa yang berdampak negatif sudah membaik. Hal ini dapat di ketahui dari keseragaman pilihan jawaban yang siswa pilih serta perilaku yang diperlihatkan selama bimbingan berlangsung.

Hal tersebut juga dapat dianalisis dengan mengetahui nilai rata-rata yang diperoleh siswa. Untuk mengetahui nilai rata-rata yang diperoleh siswa dalam menjawab pertanyaan angket konseling individu, digunakan perhitungan sebagai berikut: 
$\bar{Y}=\frac{\sum Y}{n}$

$=\frac{2515}{30}$

$=83,833$

Berdasarkan pada perhitungan di atas, telah diketahui nilai rata-rata yang diperoleh siswa sebesar 83,833. Selanjutnya untuk mengetahui standar deviasi dari skor yang diperoleh siswa dapat menggunakan perhitungan sebagai berikut:

$$
\begin{aligned}
& S D_{y}=\sqrt{\frac{n \sum Y^{2}-\left(\sum Y\right)^{2}}{n(n-1)}} \\
& S D_{y}=\sqrt{\frac{30(211025)-2515^{2}}{30(30-1)}} \\
& S D_{y}=\sqrt{\frac{6330750-6325225}{870}} \\
& S D_{y}=\sqrt{\frac{5525}{870}} \\
& S D_{y}=\sqrt{6,3505} \\
& S D_{y}=2,52
\end{aligned}
$$

Dari perhitungan di atas, telah diketahui bahwa standar deviasi angket konseling individu siswa sebesar 2,52. Selanjutnya, untuk mengetahui homogenitas atau tidaknya data yang diperoleh, maka digunakan perhitungan sebagai berikut:

$$
\begin{aligned}
& F_{\text {hitung }}=\frac{S_{x}^{2}}{S_{y}^{2}} \\
& =\frac{5,56^{2}}{2,52^{2}} \\
& =\frac{30,91}{6,35} \\
& =4,86
\end{aligned}
$$

Berdasarkan pada perhitungan di atas, telah diketahui nilai $F_{\text {hitung }}=4,86$. Sedangkan untuk menguji homogenitas suatu data, maka digunakan ketentuan diterima jika $F_{\text {hitung }}>F_{\text {tabel. }}$ Jika $F_{\text {tabel }}$ dengan taraf signifikan 0,05 adalah 3,34, maka dapat dikatakan bahwa data yang diperoleh adalah homogen. 
Selanjutnya, setelah mengetahui homogenitas data yang telah diperoleh, maka untuk pengujian hipotesisnya menggunakan perhitungan sebagai berikut:

$$
\begin{aligned}
S_{\text {gab }} & =\frac{\left(n_{e}-1\right) S_{e}^{2}+\left(n_{k}-1\right) S_{k}^{2}}{n_{e}+n_{k}-2} \\
& =\frac{(30-1) 30,91+(30-1) 6,35}{30+30-2} \\
& =\frac{896,667+184,167}{58} \\
& =\frac{1080,833}{58} \\
& =18,635
\end{aligned}
$$

Selanjutnya setelah mengetahui nilai standar deviasi gabungan (Sgab), maka dapat dilakukan perhitungan pengujian hipotesis dengan rumus uji t sebagai berikut:

$$
\begin{aligned}
& t_{\text {hitung }}=\frac{x_{y}-x_{x}}{\sqrt[s]{\frac{1}{n_{y}}+\frac{1}{n_{x}}}} \\
& =\frac{83,833-59,667}{18,635 \sqrt{\frac{1}{30}+\frac{1}{30}}} \\
& =\frac{24,163}{18,635 \sqrt{0,667}} \\
& =\frac{24,163}{18,63(0,258)} \\
& =\frac{24,163}{4,811} \\
& =5,022
\end{aligned}
$$

Hasil perhitungan rasio $t$ selanjutnya dikonfirmasi dengan nilai $t_{\text {kritis }}$ pada taraf signifikan 5\% kebebasan $(\mathrm{dk})\left(\mathrm{n}_{\mathrm{e}+} \mathrm{n}_{\mathrm{k}}-2\right.$ maka $\mathrm{t}_{\text {tabel }}=\mathrm{t}\left((1-1 / 2 \alpha)(\mathrm{dk}),\left(\mathrm{t}_{\text {tabel }}\right.\right.$ lihat lampiran $)$ Kriteria pengujian terima $\mathrm{H}$ ajika $\mathrm{t}_{\text {hitung }}>\mathrm{t}_{\text {tabel }}$. Nilai $\mathrm{t}$ dengan taraf signifikan $5 \%$ atau 0,05 . Berdasarkan pada tabel $\mathrm{t}$, nilai $\mathrm{t}_{\text {tabel }}=1,312$. Jika $\mathrm{t}_{\text {hitung }}$ telah diketahui sebesar 5,022, maka pengujian kriteria hipotesis diterima. Maka dapat disimpulkan bahwa "Konseling individu Sangat Berpengaruh Dalam Perkembangan Konsep diri Siswa Kelas X SMA Melati Binjai 2018/2019."

\section{D.KESIMPULAN}

Adapun kesimpulan dari penelitian yang dilakukan pada siswa kelas X SMA Melati Binjai Tahun Pelajaran 2018/2019 dapat peneliti uraikan sebagai berikut: 


\section{Jurnal Serunai Ilmu Pendidikan \\ Vol.3, No.2, Juni 2018 \\ e-ISSN 2621-2676}

1. Siswa membutuhkan bimbingan dan konseling dari guru BK dengan menerapkan metode yang inovatif dan berkesinambungan. Hal ini terlihat dari antusias siswa dalam mengikuti bimbingan yang peneliti lakukan dengan menerapkan metode konseling individu .

2. Konsep diri siswa dapat diatasi dengan menerapka metode konseling individu, hal ini dapat dilihat dari hasil pada penelitian ini yang menunjukkan tingkat signifikan dari data yang diperoleh peneliti.

3. Perhitungan dengan menggunakan rumus uji $\mathrm{t}$ untuk menguji hipotesis penelitian ini menunjukkan bahwa hipotesis kerja diterima, sehingga disimpulkan bahwa "Konseling individu Sangat Berpengaruh dalam Perkembc Konsep diri Siswa Kelas X SMA Melati Binjai Tahun Pelajaran 2018/2019.”

\section{DAFTAR PUSTAKA}

Arikunto, Suharsimi Prosedur Penelitian Suatu Pendekatan Praktik, Jakarta: Rineka Cipta, Edisi Revisi, 2010

Ditjen PMPTK, Rambu-Rambu Penyelenggaraan Bimbingan dan Konseling Dalam Jalur Pendidikan Formal, Jakarta: Depdiknas,2007

Luddin, Abu Bakar.M. Dasar-Dasar Konseling Tinjauan Teori dan Praktik. Bandung: Cita pustaka Media Perintis, 2010.

-Konseling Individual dan Kelompok Aplikasi Dalam Praktek

Konseling Bandung: Ciptapustaka Media Perintis, 2012

Nurihsan.Juntika.A,Strategi Lyanan Bimbingan \& Konseling, Bandung: Refika Aditama,2007

Purwanto. Ngalim.M, Psikologi Pendidikan ,Bandung :Remaja Roesdakarya:2007

Saputra, www.scribd.com/doc/11695868/Teknik-Layanan-Konseling-Perorangan, di akses tanggal 12 September 2015

Sobur. Alex,Psikologi Umum, Bandung: Pustaka Setia, 2003

Sudjana. Metoda Statistika. Bandung: Tarsito, 2005

Sugiyono, Sugiyono,Metode Penelitian Pendidikan, Cet Ke 11( Bandung: Alfabeta, 2010 